\title{
Impact of the Clinical Management of Pain: Evaluation of Stress and Coping Among Health Professionals
}

\author{
Maíra Ribeiro de Oliveira Negromonte ${ }^{1}$ \\ Tereza Cristina Cavalcanti Ferreira de Araujo²
}

\begin{abstract}
The specialist literature highlights that the clinical management of pain involves psychological difficulties associated with the pursuit of the alleviation of the suffering of patients. Therefore, an investigation was conducted into the perception of stress and coping strategies of 31 professionals of different categories from a severe burns care center (acute pain) and a pain control and palliative care unit (chronic pain). For this, a sociodemographic questionnaire, the Job Stress Scale (short version) and the Coping Strategies Inventory were applied. Compared to other categories, the nursing technicians indicated more stress factors. In compensation, they reported a greater diversity of coping strategies with significant differences between the services. These results corroborate previous studies, which warn of the adverse conditions that interfere in nursing practice. However, they also reveal the availability of protective factors, indicating perspectives of preventive intervention for the nursing team.
\end{abstract}

Descriptors: Pain; Bernout, Professional; Health Personnel.

\footnotetext{
${ }_{1}^{1}$ Psychologist, Master's Student in Psychology, Universidade de Brasília, DF, Brazil. E-mail: maira.negromonte@tjdft.jus.br. 2 Psychologist, Ph.D. in Psychology, Associate Professor, Universidade de Brasília, DF, Brazil. E-mail: araujotc@unb.br.
}

Corresponding Author:

Tereza Cristina Cavalcanti Ferreira de Araujo

Universidade de Brasília

Instituto de Psicologia. Laboratório de Saúde e Desenvolvimento Humano

Campus Darcy Ribeiro

CEP: 70910-900 Brasília, DF, Brasil.

E-mail: oliveiramai@yahoo.com.br / araujotc@unb.br 


\title{
Impacto do manejo clínico da dor: avaliação de estresse e enfrentamento entre profissionais de saúde
}

A literatura especializada destaca que o manejo clínico da dor comporta dificuldades psicológicas, associadas à busca de alívio do sofrimento dos pacientes. Sendo assim, investigaram-se a percepção de estresse e as estratégias de enfrentamento de 31 profissionais de diferentes categorias, em um centro de atendimento a grandes queimados (dor aguda) e uma unidade de controle de dor e cuidados paliativos (dor crônica). Para tanto, aplicaram-se um questionário sociodemográfico, a Job Stress Scale (versão resumida) e o Inventário de Estratégias de Coping. Comparativamente às demais categorias, os técnicos de enfermagem indicaram mais fatores de estresse. Em compensação, informaram maior diversidade de estratégias de enfrentamento com diferenças significativas entre os serviços. Esses resultados corroboram estudos anteriores, os quais alertam sobre as condições adversas que interferem na atuação em enfermagem. Porém, também revelam disponibilidade de fatores de proteção, apontando perspectivas de intervenção preventiva, destinada à equipe de enfermagem.

Descritores: Dor; Esgotamento Profissional; Pessoal de Saúde.

\section{Impacto del manejo clínico del dolor en los profesionales de la salud: evaluación de estrés y enfrentamiento}

\begin{abstract}
La literatura especializada destaca que el manejo clínico del dolor produce dificultades psicológicas asociadas a las actividades realizadas para aliviar el sufrimiento de los pacientes. Siendo así, se investigaron la percepción del estrés y las estrategias para enfrentarlo en 31 profesionales de diferentes categorías en un centro de atención a quemaduras de gran tamaño (dolor agudo) y una unidad de control del dolor y cuidados paliativos (dolor crónico). Para esto, se aplicó un cuestionario sociodemográfico, la Job Stress Scale (versión resumida) y el Inventario de Estrategias de Coping. Comparado con las demás categorías, los técnicos de enfermería indicaron más factores de estrés. En compensación, informaron mayor diversidad de estrategias de enfrentamiento con diferencias significativas entre los servicios. Estos resultados corroboran estudios anteriores, los cuales alertan sobre las condiciones adversas que interfieren en la actuación en enfermería. Sin embargo, también revelan la disponibilidad de factores de protección, apuntando perspectivas de intervención preventiva destinadas al equipo de enfermería.
\end{abstract}

Descriptores: Dolor; Agotamiento Profesional; Personal de Salud.

\section{Introduction}

Patients who suffer from chronic pain, and severe burn patients that experience acute pain, are usually assisted by a multidisciplinary team composed of physicians, nurses, physical medicine professionals, and psychologists, among others ${ }^{(1-2)}$. Treating these patients constitutes a challenging and often frustrating task for the agents involved. It is noteworthy that the stress levels of caregivers are influenced by the reactions of the patients, who may present depression or anxiety ${ }^{(3)}$ before treatments that induce many collateral effects with little immediate relief of suffering $(2,4)$. Added to this is the overload of work and the difficulties caused by their participation in a team composed of professionals of heterogeneous training(5-6). In fact, the specialized literature reveals increasing interest in the care of those who perform the role of caregivers ${ }^{(7-8)}$. This trend is due, in part, to the verification of pathological reactions triggered by the act of caring. It is worth insisting that besides affecting the patient, the experiences provoked by pain contaminate their family and the rest of their socio-emotional context, including the professionals with whom they interact in the service ${ }^{(9)}$. The change 
in attitude of the health professionals themselves, who have started to admit their need for care in some circumstances $^{(8)}$, also contributes to the development of studies on the subject.

According to the transactional $\operatorname{model}^{(10)}$, it is not possible to comprehend the stress by examining the environmental events and the responses of the individual separately. Both should be comprehended as a transaction, in which each individual seeks to adjust to the quotidian challenges ${ }^{(11)}$. Thus, the exchanges between people and the environment occur through a cognitive evaluation, in which the following are analyzed: whether the situation threatens the well-being; whether the resources are sufficient to cope; and, during the cycle, whether the chosen strategy is effective ${ }^{(12)}$. In the 1970s, Robert Karasec and other pioneering researchers showed that working relationships represent a generator source of stress with health repercussions. They proposed a bidimensional model that relates psychological demand and the control of the risks of becoming ill. According to its supporters, the psychological demand refers to quantitative factors such as time and speed in performing the work, and qualitative factors, such as conflicts arising from contradictory requests. The control corresponds to making possible the use of intellectual abilities and decision making regarding how to conduct the work activity ${ }^{(13)}$. Therefore, the coexistence of high psychological demands with low control generates professional distress and may have a negative impact on the health of the worker(14). These conditions typically characterize the practice of the health professionals, who are subjected to constant tension due to the nature of their actions with people whose physical, mental and social integrity is affected, as well as due to the need to manage complex institutional issues associated with public policies and the exchange between different professional categories $^{(7)}$.

Coping is commonly defined as cognitive and behavioral efforts to deal with (reduce, dominate or tolerate) the external demands of the individualenvironment relationship, which are evaluated as overloading or exceeding the personal resources ${ }^{(15)}$. This definition comes from the model proposed by Lazarus and Folkman(10), which advocates coping as a process resulting from reciprocal responses between individuals and their context over a period of time ${ }^{(16)}$. This is a moderator of the events evaluated as stressful, which can reduce the severity of the symptoms ${ }^{(17)}$. The coping strategy would be considered effective when the behavior alleviated the uncomfortable feelings raised by threats or losses. It would be considered ineffective, when it was not possible to deal with the stressful situation in a successful manner, which could trigger psychological and physiological imbalances(18).

In summary, in view of the scientific and professional interest in the area of health, an investigation was carried out into the perception of stress and coping strategies adopted by the professionals of specialized teams in the monitoring of patients with acute and chronic pain.

\section{Method}

\section{Participants}

The purposive sample was constituted by professionals of different categories from a severe burns monitoring service (SBMS) and a chronic pain and palliative care service (CPPCS). Table 1 presents the main characteristics of these participants.

Table 1 - Characterization of the professionals

\begin{tabular}{lccc}
\hline & SBMS & CPPCS & Total \\
\hline Men & 10 & 0 & 10 \\
Women & 16 & 5 & 21 \\
Physicians & 6 & 2 & 8 \\
Nursing technicians & 10 & 2 & 12 \\
Nurses & 3 & 1 & 4 \\
Other graduate professionals & 7 & 0 & 7 \\
Between 20 and 35 years of age & 0 & 8 & 8 \\
Between 36 and 50 years of age & 1 & 15 & 16 \\
Over 50 years of age & 4 & 3 & 7 \\
Up to 1 year of work in the service & 0 & 8 & 8 \\
Between 1 and 5 years of work in the service & 1 & 6 & 7 \\
Between 5 and 10 years of work in the & 4 & 5 & 9 \\
service & & 7 & 7 \\
More than 10 years of work in the service & 0 & 7 \\
Participated in training to deal with pain & 2 & 3 & 5 \\
Had not participated in training to deal with & 24 & 2 & 26 \\
pain & &
\end{tabular}

\section{Instruments}

Sociodemographic questionnaire for characterization of the sample

Coping Strategies Inventory of Folkman and Lazarus (adapted into Portuguese)(19), comprising 66 items that classify the coping strategies into eight factors (confrontation, distancing, self-control, social support, accepting responsibility, escape-avoidance, problem solving and positive reappraisal) and according to the intensity (I did not use this strategy, I used it a little, I used it, and I used it very much).

Job Stress Scale, the reduced version adapted to 
Portuguese ${ }^{(14)}$, encompassing 17 items for the evaluation of demand, control and social support perceived by the worker, which are measured on a Likert scale of four points (ranging between often and never/almost never or between strongly agree and strongly disagree).

\section{Procedures for collecting and analyzing data}

The study was previously approved by a Research Ethics Committee and the agreement of the professionals was obtained by signing the Terms of Free Prior Informed Consent (TFPIC). Initially, the Sociodemographic Questionnaire was applied followed by the scale and the inventory, respectively. For data analysis, the statistical package SPSS version 17.0 was used. As the distribution of participants in the majority of groups based on the antecedent variables, was less than 15, the use of nonparametric tests was chosen to obtain descriptive, comparative statistics and, in a few cases, correlations.

\section{Results}

\section{Stress}

Regarding the psychological demands, the scores obtained ranged from 12 to 22 , with an associated mean of 17.7. These values indicate the existence of demands at higher levels than the expected median (15). Similarly, the factor control reached values between 16 and 29 and an associated mean of 22.9, also above the expected median (18). Regarding social support, considered to be a moderating factor of work stress, a mean value of 18.2 was verified, which is slightly higher than the expected median (between 12 and 18). Comparing the four groups identified in the professional categories (antecedent variable) with the factors proposed by the Job Stress Scale, statistically significant differences were found in the dimensions control and social support (Figure 1).

With regard to the factor control, it was ascertained that the mean values indicated by the graduate professionals were significantly different from those estimated by the nursing technicians. In other words, physicians, nurses and other graduate categories reported having more control over the work activity than nursing technicians. However, physicians and nurses perceived receiving more social support than nursing technicians and other graduate professionals. No significant differences were verified between the two teams surveyed with regard to the factors of the Job Stress Scale.

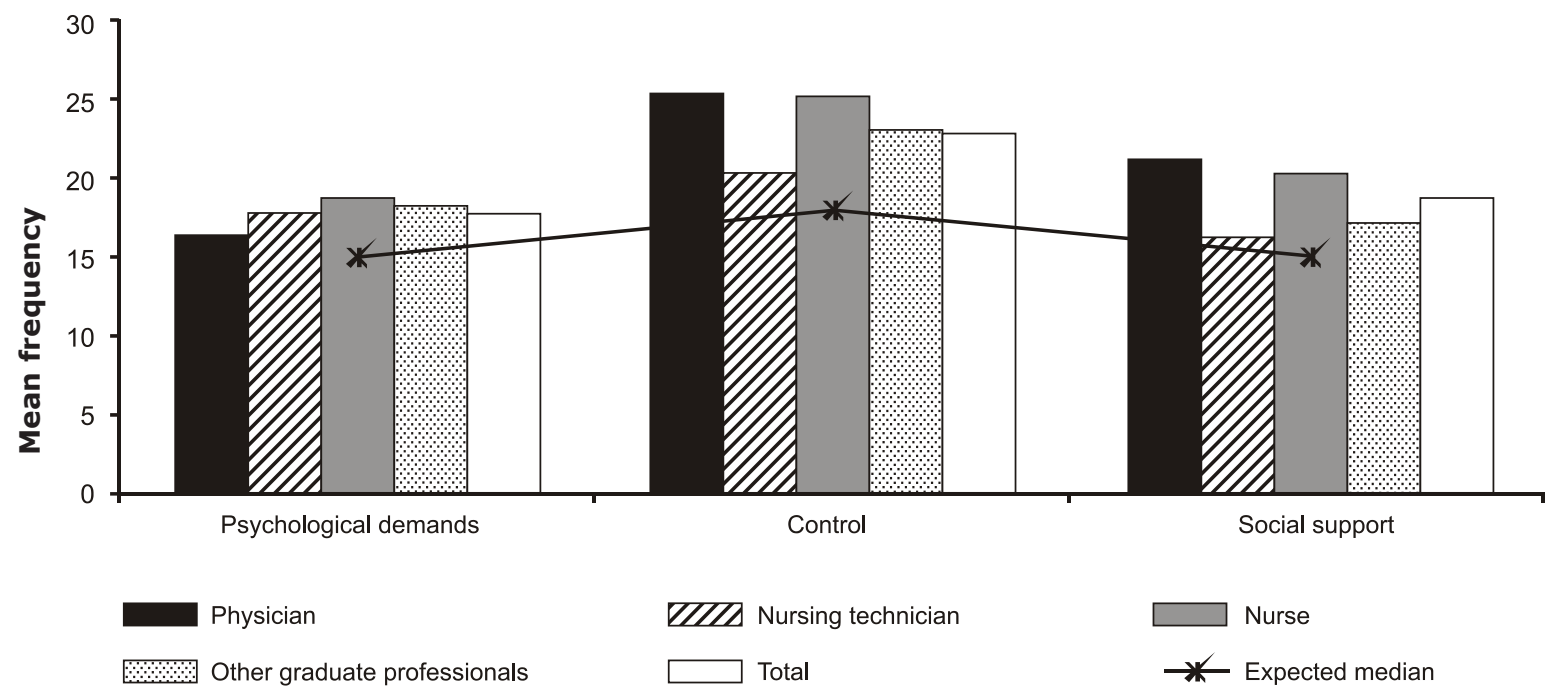

Figure 1 - Distribution of the Job Stress Scale factors for the professional groups

\section{Coping}

All factors relating to the Coping Inventory achieved means congruent with the median values expected. The coping strategies used most often encompassed the following factors in ascending order: escapeavoidance, confrontation, self-control, problem solving, withdrawal, social support, accepting responsibility and positive reappraisal.

As illustrated in Figure 2, significant differences were found between the members of the SBMS (acute pain) and the CPPCS (chronic pain) in relation to the confrontation and resolution of problems $(U=29, p=0.05$ and $U=22, p=0.02$, respectively). It is important to highlight that the professionals of the CPPCS reported using more of the strategies grouped in these factors. 


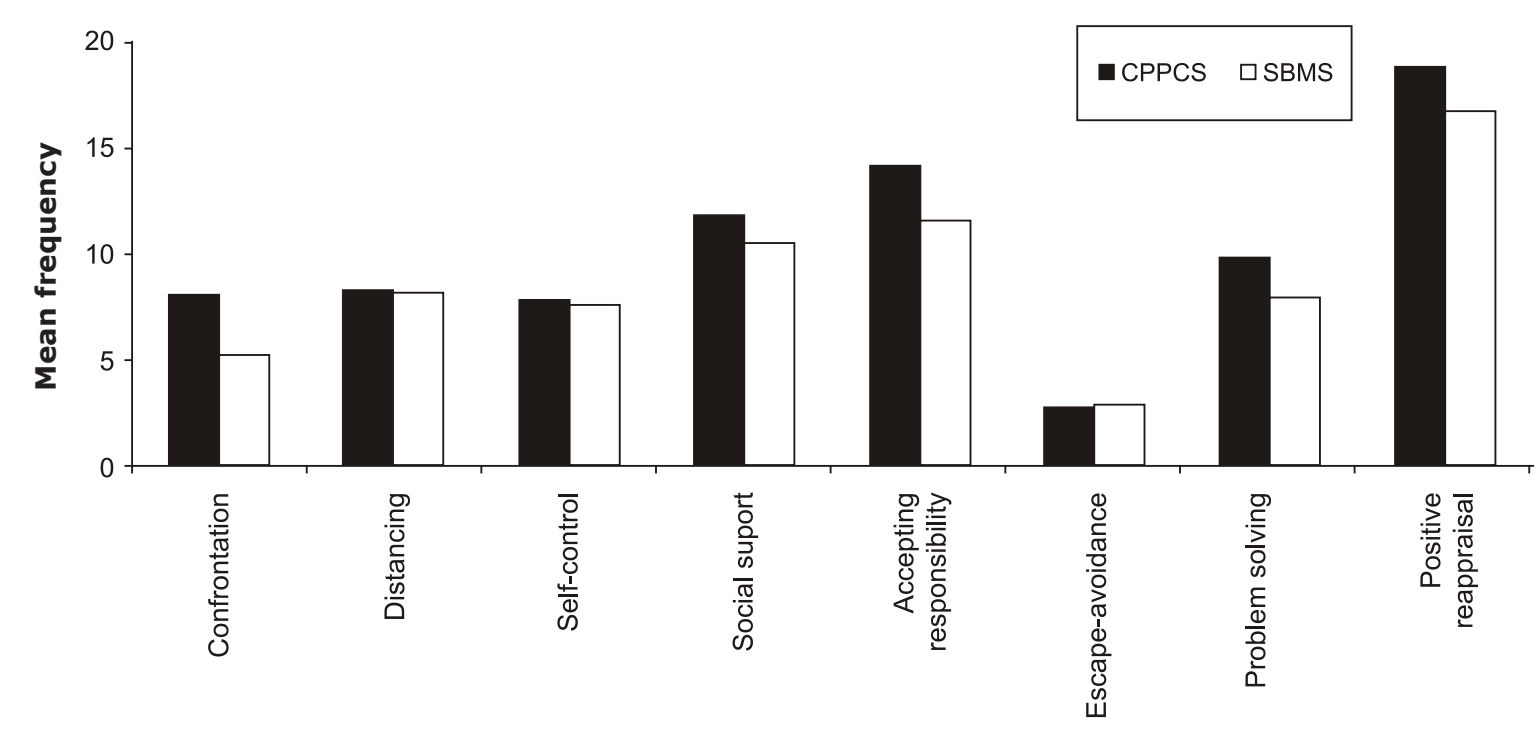

Figure 2 - Distribution of the Coping Inventory factors by service

From the data gathered through the Sociodemographic Questionnaire regarding the participation, or not, in specific training for the clinical management of pain, differences in the factor problem solving were identified. That is, in general, the professionals who responded positively to the enquiry adopted more strategies linked to problem solving than those who did not mention this training program.

\section{Discussion}

The overall results obtained from the Job Stress Scale indicated high levels of psychological demands. Conversely, they also highlighted higher levels of control in the work and social support received. Such a situation, in which high psychological demands are associated with high control, reveals that the participants experience their work actively. That is, although the psychological demands are excessive, they are less harmful, since the worker can develop strategies to cope with the difficulties $^{(14)}$. Furthermore, the adverse conditions of the work context of the studied teams also seem to ease when high levels of positive social interaction are detected. However, when analyzing each of the professional categories separately, specificities emerged. Thus, while the indexes related to the perception of psychological demands were presented as equally high for all categories, differences were verified between control and social support in the area of nursing. It is worth reflecting that the low mean scores achieved by the nursing technicians can be comprehended by considering the persistence of a strong hierarchy in the health services, despite the nefarious consequences of this mode of organization, already widely discussed in the literature ${ }^{(20)}$. In the case of the nurses who achieved higher values, it must be remembered that they assume the administrative coordination of the services and the leadership of the nursing staff. Due to this function, they concentrate much of the information regarding the operation of the service and the clinical condition of the patients, by increasing their interaction with the other members of the multidisciplinary team and ensuring greater autonomy in establishing their work routines. This peculiarity can clarify the data found in this category.

It is worth mentioning that, in the SBMS, the burn remains as an acute pathological condition that demands, at least in the initial phases of care, actions geared primarily to maintaining the vital signs of the patient. In the CPPCS there are peculiarities inherent in the outpatient context in which complaints related to chronicity predominate, such as the terminality, which require a high complexity of care $^{(2)}$. In these circumstances, the high levels of social support perceived by the professionals can be generated by feelings of intense frustration due to the recurrence of therapeutic weaknesses ${ }^{(9)}$, which ultimately favor an approach known as integrative metatheory. This is a perspective where the different dimensions interact in the health-disease process and enable effective multidisciplinary practice ${ }^{(20)}$. Similarly, it can be observed that the chronicity provokes changes that mainly affect the relationship of the physician with the other health professionals and with the patient ${ }^{(2)}$. 
Regarding the factors of the Coping Inventory, when the services were compared, some distinctions were observed: professionals of the SBMS tend to use fewer strategies categorized as confrontation and problem solving than the professionals of the CPPCS. It should be considered that, on one hand, the SBMS is a large service, composed of an extensive and differentiated team that provides 24 hours care (clinical, surgical and rehabilitation). Due to this diversity and coverage, a shared, yet paradoxically impersonal, responsibility is assumed, which expresses itself through reduced individual use of strategies focused on confronting the situation and problem solving. On the other hand, in the CPPCS, patients often receive prescription medication or guidelines of conduct in each of the consultations with the various professionals, and it is expected that the strategies for confronting the situation and problems solving are more frequent.

Finally, a comparison of the stress and coping indicators infer that high levels of control in the work are linked preferentially to strategies classified as problem solving. Similarly, the presence of high psychological demands suggests the use of strategies focused on positive reappraisal. It is also relevant to note that both the Job Stress Scale and the Coping Inventory determined the availability of an effective social support network in the work context.

\section{Conclusion}

This study showed that the nursing technicians are subjected to more stress than the other categories, including nurses. In compensation, the nursing categories mobilize a greater diversity of coping strategies. These results warn of the adversities that interfere in nursing practice. Protective factors were also identified, which can support proposals for preventive intervention aimed at the nursing team. In other words, it is essential to strengthen the coping strategies already employed and to introduce other modalities indicated by the literature and acceptable in the context of each team, depending on their specialization in the care of patients with acute or chronic pain. It is equally crucial to organize and offer continuing education courses, aimed at the qualification and training of these teams, which are based on previously developed studies. Further studies are recommended to better elucidate the conditions that promote and hinder the effective and efficient multidisciplinary teamwork in the context of services that treat patients with pain. It is essential to evaluate more fully and accurately the impact of the clinical management of pain on the health of the professionals and consequently on the quality of life and well-being of the users.

\section{References}

1. Baszanger I. Pain: its experience and treatment. Soc Sci Med. 1989;29(3):181-215.

2. Lima MAG, Trad L. Dor crônica: objeto insubordinado. Hist Ciênc Saúde - Manguinhos. 2007;15(1):117-33. 3. Castro MMC, Quarantini L, Batista-Neves S, Kraychete DC, Daltro C, Miranda-Scippa A. Validade da escala hospitalar de ansiedade e depressão em pacientes com dor crônica. Rev Bras Anestesiol. 2006;56(5):470-7.

4. Teixeira MJ, Figueiró JAB, Yeng LT. Tratamento multidisciplinar em doentes com dor. In: Carvalho MMMJ. Dor: um estudo multidisciplinar. São Paulo (SP): Summus; 1999. p. 87-139.

5. Queiroz E, Araujo TCCF. Trabalho em equipe: um estudo multimetodológico em instituição hospitalar de reabilitação. Interam Psychol. 2007;41(2):221-30.

6. Costa $C B$ Neto. Fatores do processo de tomada de decisão da equipe de saúde numa instituição de tratamento a irradiados por fonte ionizante: um estudo de caso [dissertação de mestrado]. Brasília (DF): Instituto de Psicologia da Universidade de Brasília; 1994. $315 \mathrm{p}$.

7. Campos EP. Equipe de saúde: cuidadores sob tensão. Epistemo-somática. 2006;3(2):195-222.

8. Carvalho V. A equipe de saúde e suas vicissitudes emocionais. In: Pimenta CAM, Mota DDCF, Cruz DALM. Dor e cuidados paliativos. São Paulo (SP): Manole; 2006. p. 103-23.

9. Maciel MGS. Dor crônica no contexto dos cuidados paliativos. Prática Hosp. [internet]. 2004 [acesso: 30 outro 2010];6(35). Disponível em: http://www. praticahospitalar.com.br/pratica\%2035/paginas/ materia\%2005-35.html

10. Lazarus RS, Folkman S. Stress, apraisal and coping. 9th.ed. New York: Springer; 1984. 445 p.

11. Straub RO. Estresse. In: Straub RO. Psicologia da saúde. Porto Alegre (RS): Artmed; 2004. p. 115-49.

12. Lazarus RS. [Do estresse psicológico às emoções: uma história de mudança de pontos de vista]. Ann Rev Psychol. 1993;44:1-22. Inglês.

13. Ulhoa MA, Moreno CRC. Fatores psicossociais no trabalho e cortisol: breve revisão. Interfacehs. 2009;4(3):63-73.

14. Alves MGM, Chor D, Faerstein E, Lopes CS, Werneck, GL. Versão resumida da Job Stress Scale. Rev Saúde 
Pública. 2004;38(2):164-71.

15. Folkman S, Lazarus RS, Dunkel-Schetter C, DeLongis A, Gruen RJ. [Dinâmicas de um encontro estressante: avaliação cognitiva, enfrentamento e resultados do encontro]. J Person Soc Psychol. 1986;50(5):9921003. Inglês.

16. Gimenes MGG. A teoria do enfrentamento e suas implicações para os sucessos e insucessos da psiconcologia. In: Gimenes MGG. A mulher e o câncer. Campinas (SP): Psy; 1997. p. 111-48.

17. Murta SG, Laros JA, Tróccoli BT. Manejo de estresse ocupacional na perspectiva da área de avaliação de programas. Est Psicol. 2005;10(2):167-76.

18. Lorencetti A, Simonetti JP. As estratégias de enfrentamento de pacientes durante o tratamento de radioterapia. Rev. Latino-Am. Enfermagem. 2005;13(6):944-50.

19. Savoia MG, Santana P, Mejias NP. Adaptação do Inventário de Estratégias de Coping de Folkman e Lazarus para o português. Psicol USP. 1996;17(7):227-38.

20. Reis JC. Modelo metateórico da psicologia da saúde para o século XXI: interação ou integração biopsicossocial? Análise Psicol. 1999;17(3):415-33. 